\title{
STRATEGI PEMASARAN KERAJINAN KAYU EBONY PADA TOKO KRISNA KARYA DI KOTA PALU
}

\author{
JAURA \\ HARIFUDDIN THAHIR \\ FARID \\ Program Studi SI Manajemen Fakultas Ekonomi Universitas Tadulako \\ Email: jaura.jasman94@gmail.com
}

\begin{abstract}
Abstrack
The objectives of this research are to analyze the strategies used by Krisna Karya in increasing ist sales and to find out the factors of Strength, Weasness, Opportunities and Threats (SWOT) in marketing its products. This research is descriptive by using field research approach that the research done directly to Krisna Karya shop which aims to analyze marketing strategy of Krisna Karya shop. The results of this research can be concluded that the SWOT analysis show that the External Strategic Factor Analysis Summary (EFAS) or opportunities and threast of Krisna Karya shop with the total is 3.31 and Internal Strategic Factor Analysis Summary (IFAS) or strengths and weaknesses of 3.01 of these results should be souvenir shop of Krisna Karya using SO strategy by utilizing all the power of effort in order to seize and utilize opportunities that exist optimaly.

Keywords:Marketing Strategy, SWOT Analysis

Abstrak

Penelitian ini bertujuan untuk mengetahui serta menganalisis strategi yang digunakan Krisna Karya dalam meningkatkan penjualannya dan untuk mengetahui faktor-faktor kekuatan, kelemahan, peluang dan ancaman Krisna Karya dalam memasarkan produknya. Penelitian ini bersifat deskriptif dengan menggunakan pendekatan penelitian lapangan (field research) yakni penelitian yang dilakukan dengan langsung ke Krisna Karya yang bertujuan menganalisis Strategi Pemasaran Krisna Karya tersebut. Hasil penelitian ini dapat ditarik kesimpulan bahwa pada hasil analisis SWOT, menunjukkan external strategic factor analysis summary (EFAS) / peluang dan ancaman usaha Toko Krisna Karya dengan total 3,31 dan internal strategic factor analysis summary (IFAS) / kekuatan dan kelemahan sebesar 3,01 dari hasil tersebut sebaiknya usaha toko souvenir Krisna Karya menggunakan strategi SO yaitu dengan memanfaatkan semua kekuatan usaha dalam rangka merebut dan memanfaatkan peluang yang ada secara optimal.
\end{abstract}

\section{Kata Kunci: Strategi Pemasaran, Analisis SWOT.}

\section{PENDAHULUAN}

Salah satu tanaman yang potensial untuk dikembangkan sebagai agroindustri di Sulawesi Tengah yakni kayu Ebony. Pohon ini menghasilkan kayu yang berkualitas sangat baik. Warna kayu coklat gelap, kehitaman atau hitam berbelang-belang kemerahan, hitam. Kayu Sulawesi ini dalam perdagangan internasional dikenal sebagai Macassar ebony, Coromandel Ebony,Streaked Ebony atau juga Black Ebony. Berat jenis kayu Ebony melebihi berat jenis air, sehingga tidak dapat mengapung. Jenis kayu Ebony ini sangatlah unik dan jarang didapatkan di negara-negara lain, karena keunikan kayu ini banyak industri kerajinan tangan memanfaatkan kayu ini untuk dijadikan berbagai souvenir dan furniture. Jenis kayu ini dapat memberikan nilai tambah terhadap produk yang dihasilkan sehingga dapat meningkatkan pendapatan dari industri yang memanfaatkan jenis kayu tersebut (Amelia, Antara, \& Yulianti, 2014). Industri Kerajinan kayu Ebony "Krisna Karya" merupakan salah satu industri kerajinan kayu Ebony dari sekian banyak industri kerajinan kayu Ebony yang ada di Kota Palu. Industri ini juga masih aktif berproduksi tiap tahunnya dibandingkan dengan industri-industri lain yang ada di Kota Palu. 
Keberhasilan suatu perusahaan dapat diketahui dan diukur dengan melihat kemampuan perusahaan dalam memperoleh keuntungan dalam periode tertentu. Perusahaan dalam menjalankan aktivitasnya baik perusahaan yang bergerak dalam bidang jasa maupun barang mempunyai tujuan yang sama yaitu memperoleh keuntungan. Selain itu perusahaan juga ingin memberikan kepuasan kepada konsumen atas produk yang dihasilkannya, karena kepuasan konsumen menjadi tolak ukur dari keberhasilan perusahaan dalam menghasilkan produk yang berkualitas dan diinginkan oleh konsumen. Melihat potensi industri kerajinan kayu Ebony Krisna Karya yang begitu menonjol terhadap pencapaian hasil penjualan produksinya hal tersebut tidak terlepas dengan berbagai strategi-strategi pemasarannya. Untuk daftar toko souvenir kayu Ebony yang ada di Kota Palu dapat di lihat pada tabel 1 dibawah ini.

Tabel 1

Daftar Nama Toko Souvenir Kayu Ebony Di Kota Palu

\begin{tabular}{|c|l|l|}
\hline No & \multicolumn{1}{|c|}{ Nama Toko } & \multicolumn{1}{c|}{ Alamat Toko } \\
\hline 1 & Bunga Kaili & Bandar Udara Sis Aljufri \\
\hline 2 & Rhema & Jl. Basuki Rahmat \\
\hline 3 & Diverso & Jl. Kartini \\
\hline 4 & Diana & Jl. Kartini \& jl. Dayodara \\
\hline 5 & Sal-Han & Jl. Sis Aljufri \\
\hline 6 & Banjar Kios & Jl. Imam Bonjol \\
\hline 7 & CV. Immanuel Ebony Woodcraft & Jl. Trans Mamboro \\
\hline 8 & Sumber Urip Eboni & Jl. Sisingamangaraja \\
\hline 9 & NS. Souvenir & Jl. Sparman \\
\hline 10 & Ebony & Jl. Kayumalue \\
\hline 11 & Souvenir Priangan & Jl. Suekarno Hatta \\
\hline 12 & Raflly Ebony & Jl. Suekarno Hatta \\
\hline 13 & Surya Ebony & Jl. Suekarno Hatta \\
\hline 14 & Linda Ebony & Jl. Sungai Sausu \\
\hline
\end{tabular}

Sumber: UMKM KOTA PALU, 2018

Berdasarkan latar belakang di atas, menjadi dasar pertimbangan penulis untuk mengetahui bagaimana penerapan strategi pemasaran yang dilakukan Krisna Karya Kota Palu dalam meningkatkan volume penjualannya dengan demikian penulis memilih judul skripsi sebagai berikut: "Strategi Pemasaran Kerajinan Kayu Ebony Pada Toko Krisna Karya di Kota Palu”.

\section{KAJIAN LITERATUR DAN PENGEMBANGAN HIPOTESIS}

\section{Pemasaran}

Menurut Rangkuti (2015:101) pemasaran adalah suatu proses kegiatan yang dipengaruhi oleh berbagai faktor sosial, budaya, politik, ekonomi dan manajerial. Akibat dari pengaruh berbagai faktor tersebut adalah masing-masing individu maupun kelompok mendapatkan kebutuhan dan keinginan dengan menciptakan, menawarkan, dan menukarkan produk yang memiliki nilai komoditas.

Pemasaran (marketing) adalah mengidentifikasi dan memenuhi kebutuhan manusia dan sosial. Salah satu definisi yang baik dan singkat dari pemasaran adalah "memenuhi kebutuhan dengan cara menguntungkan". American Marketing Association memberikan defenisi formal sebagai berikut : Pemasaran adalah suatu fungsi organisasi dan serangkaian proses untuk menciptakan, mengomunikasikan, 
dan memberikan nilai pada pelanggan dan untuk mengelola hubungan pelanggan dengan cara yang menguntungkan organisasi dan pemangku kepentingannya. (Kotler dan Keller 2009:5).

\section{Manajemen Pemasaran}

Menurut Kotler dan Keller (2009:5) Manajemen pemasaran (marketing management) sebagai seni dan ilmu memilih pasar sasaran dan meraih, mempertahankan, serta menumbuhkan pelanggan dengan menciptakan, menghantarkan, dan mengomunikasikan nilai pelanggan yang unggul.

\section{Strategi Pemasaran}

Menurut Malau (2017:222) Strategi pemasaran secara konseptual sangat sederhana. Hal ini dimulai dengan analisis pasar yang dipertimbangkan organisasi. Hal ini memerlukan analisis rinci dari kemampuan organisasi, kekuatan dan kelemahan pesaing, kekuatan ekonomi dan teknologi yang mempengaruhi pasar, dan pelanggan saat ini dan potensi di pasar.

\section{Aplikasi Strategi Pemasaran}

Berikut ini merupakan proyeksi kuadran dan sekaligus aplikasi strategi dalam proses pemasaran karena hal itu adalah dijadikan sebagai bentuk tolak ukur untuk tetap eksis dan bertahan diantaranya posisi kuadran Star, posisi kuadran Problem Child or Wildcat, posisi kuadran Dog dan posisi kuadran Cash Cow Ratz (2011).

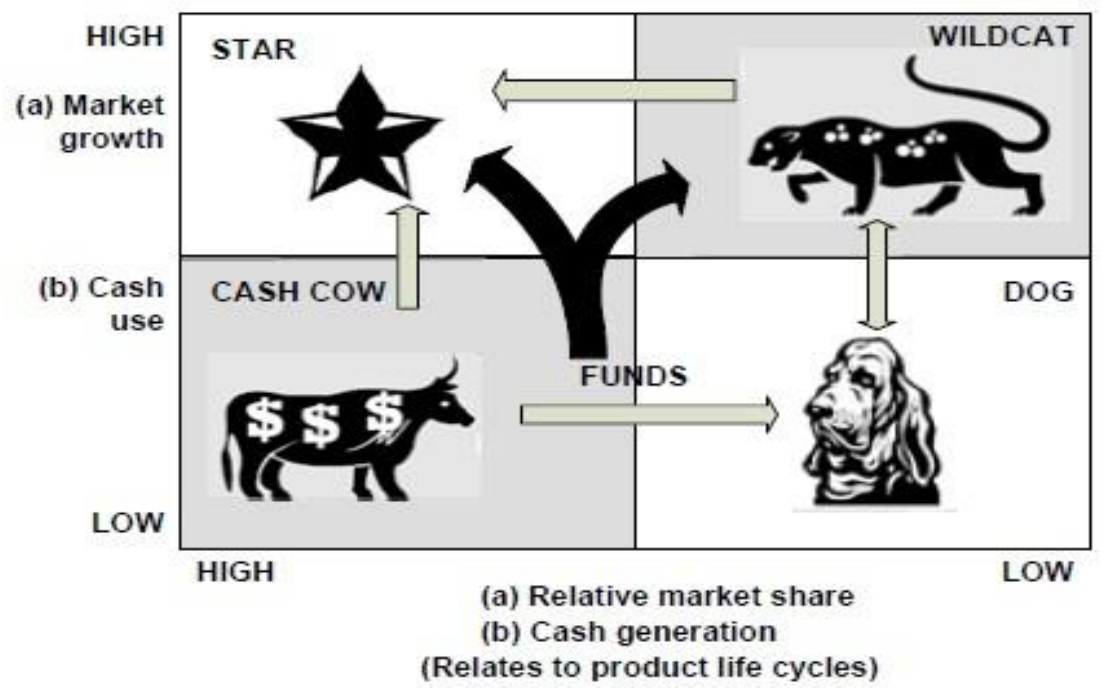

\section{Kuadran Star}

Kuadran ini memberikan gambaran bahwa product atau service dari organisasi bisnis yang mempunyai tingkat pertumbuhan demand dan potensial keuntungan atau profit yang tinggi sehingga membentuk market share yang tinggi. Maka, produk organisasi yang berada pada kuadran ini secara umum mempunyai tingkat revenue yang signifikan, sehingga strategi investasi mengarah pada kebutuhan untuk mempertahankan posisi yang sudah ada.

\section{Kuadran Problem Child or Wildcat}

Kuadran ini menggambarkan posisi produk organisasi bisnis berada pada tingkat kebutuhan pasar atau market growth yang tinggi tetapi market share yang terbentuk rendah, sehingga membutuhkan investasi yang signifikan atau berlebih dengan harapan dapat memperoleh market share yang tinggi dan dapat menuju pada posisi kuadran Star. 


\section{Kuadran Dog}

Kuadran ini menggambarkan posisi produk dan organisasi secara umum berada posisi yang tidak menguntungkan secara finansial, karena market share dan market demand secara keseluruhan turun. Sama halnya dengan posisi kuadran III Usaha menghadapi peluang pasar yang sangat besar tetapi di lain pihak, ia menghadapi beberapa kendala/kelemahan internal.

\section{Kuadran Cash Cow}

Kuadran ini menggambarkan posisi produk dan organisasi secara umum berada posisi pertumbuhan market demand yang lambat karena tidak disertai dengan pertumbuhan pelanggan, sehingga revenue yang didapat oleh produk dari kuadran Star dibutuhkan untuk re-investasi. Sehingga membutuhkan strategi pemasaran yang lebih efisien dan efektif agar produk dapat lebih dikenal dan dapat meningkatkan aspek market share-nya dan posisi kuadran IV merupakan situasi yang sangat tidak menguntungkan, usaha tersebut menghadapi berbagai ancaman dan kelemahan internal.

\section{Analisis SWOT}

Analisis SWOT adalah analisis informasi yang diperoleh, dicari, atau di terima dari berbagai sumber hasil dari pertanyaan: apa yang sedang terjadi, kenapa terjadi, dimana terjadi dan kapan terjadi, yang semuanya berasal dari internal perusahaan dan eksternal berkaitan dengan usaha perusahaan. Analisis ini ditunjukan untuk mengukur besarnya kekuatan dan kelemahan perusahaan secara keseluruhan, serta kesempatan dan ancaman yang ada diluar perusahaan. (Sabariah 2016:41).

Setelah kita mengetahui kekuatan dan kelemahan, kesempatan yang terbuka, serta ancaman-ancaman yang dialaminya, maka kita dapat menyusun suatu rencana atau strategi yang mencakup tujuan yang telah ditentukan. " apabila kita telah mengenal kekuatan dan kelemahan lawan sudah dapat dipastikan bahwa kita akan dapat memenangkan pertempuran". Dasar ajaran dari Tzu (2004) adalah bahwa bila strategi anda mempunyai dasar yang kuat, anda akan menang dan bila anda mempunyai strategi yang benar-benar hebat, anda akan menang tanpa bertempur.

\section{Kerangka Pikir}

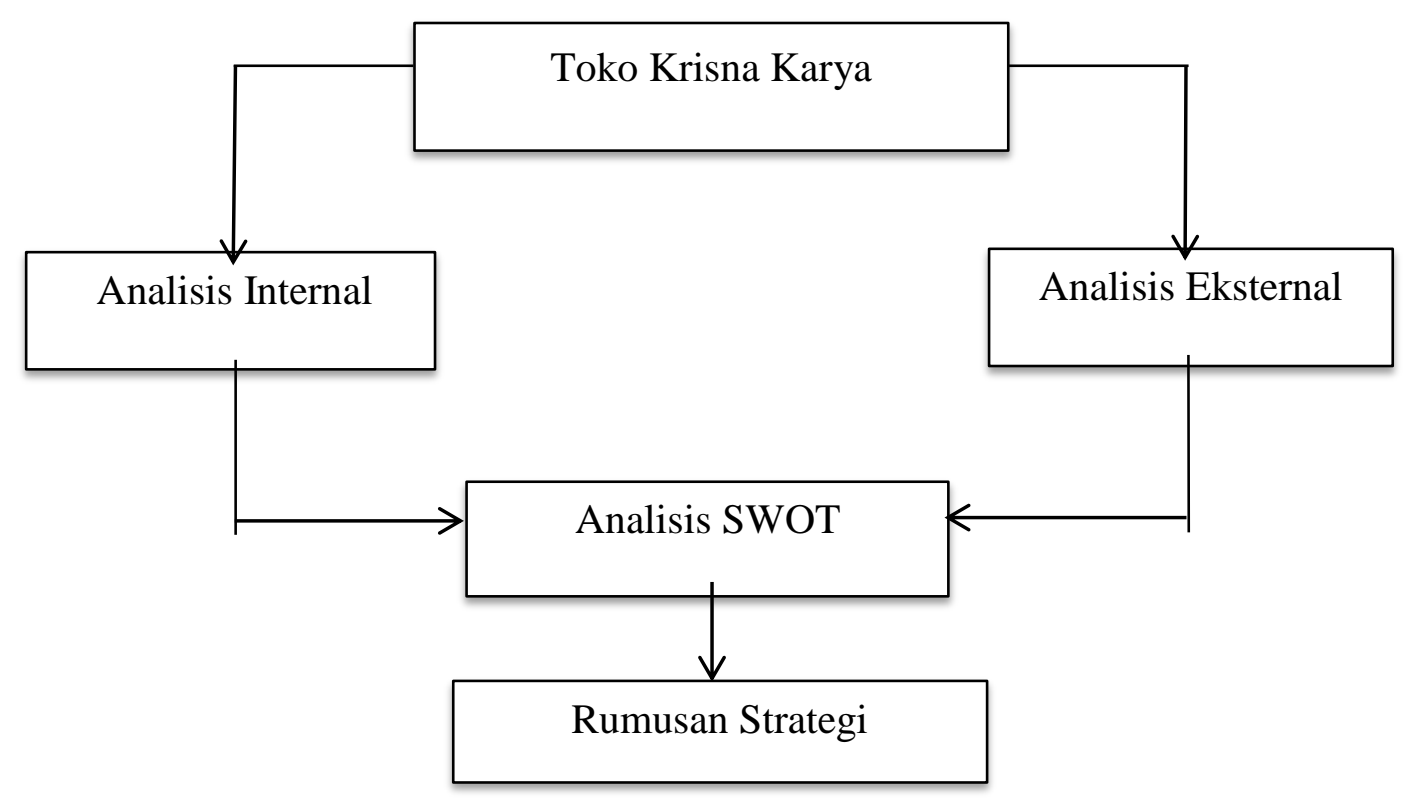

Gambar 1 Kerangka Pikir 


\section{METODE PENELITIAN}

\section{Jenis Penelitian}

Penelitian ini dilakukan bersifat deskriptif dengan menggunakan pendekatan penelitian lapangan (field research) yakni penelitian yang dilakukan dengan langsung ke Toko Krisna Karya yang bertujuan menganalisis Strategi Pemasaran Krisna Karya tersebut. Menurut Afrillita (2013:63) penelitia deskriptif merupakan metode penelitian yang berusaha menggambarkan suatu objek sesuai dengan keadaan atau apa adanya

\section{Lokasi Penelitian}

Berdasarkan penyusunan penelitian penulis melakukan penelitian pada Toko Krisna Karya yang berlokasi di jalan Samratulangi no 51 Kota Palu. Di mana alasan penulis memilih objek tersebut karena selain menjadi supplier pertama Krisna Karya juga dapat memproduksi barang sendiri.

\section{Jenis dan Sumber Data}

Jenis data yang digunakan dalam penelitian ini adalah data kualitatif adalah data yang tidak terukur berupa tulisan-tulisan atau keterangan-keterangan dan gambaran-gambaran yang menjelaskan tentang halhal yang berhubungan dengan penelitian ini dan masalah yang dibahas. Data kuantitatif adalah data terukur berupa angka-angka, jumlah maupun hasil perhitungan yang di peroleh langsung dari perusahaan yang akan diolah lebih lanjut secara sistematis.

Sumber data yang digunakan adalah data primer adalah data yang diambil dari sumber data secara langsung penelitian atau mewakilinya dimana penelitian melakukan penelitian sendiri dengan cara interview, yaitu melakukan tanya jawab atau wawancara langsung dengan pemimpin, karyawan maupun pelanggan dan pesaing perusahaan lain. Terhadap kondisi internal dan eksternal pada Krisna Karya. Data sekunder adalah data yang diperoleh melalui penelitian pustaka, yaitu dengan mempelajari dan menelaah pendapat-pendapat yang bersifat teoritis dan literatur-literatur yang mempunyai kaitan dengan obyek yang diteliti yaitu gambaran umum Krisna Karya, struktur Krisna Karya dan data karyawan Krisna Karya.

\section{Populasi dan Sampel}

Populasi adalah wilayah generalisasi yang terdiri atas: objek/subyek yang mempunyai kualitas dan karakteristik tertentu yang diterapkan oleh peneliti untuk dipelajari dan kemudian ditarik kesimpulannya (Sugiyono,2014:115). Sampel adalah sebagian atau wakil populasi yang diteliti . Pengambilan sampel dilakukan dengan teknik purposive atau dengan cara sengaja dalam menentukan responden yang totalnya 8 orang yaitu 1 orang manajer, 5 orang karyawan dan 2 orang pelanggan.

\section{Metode Pengumpulan data}

Untuk memperoleh data yang digunakan dalam penelitian ini, maka penulis menggunakan beberapa metode pengumpulan data, yaitu:

a. Observasi, yaitu pengamatan secara langsung terhadap obyek penelitian, cara ini dapat memberikan informasi yang lebih akurat berdasarkan kenyataan yang ada.

b. Wawancara, yaitu peneliti melakukan serangkaian Tanya jawab secara langsung kepada pemilik Krisna Karya mengenai kondisi internal dan eksternal perusahaan yang berhubungan dengan strategi pemasaran yang diterapkan.

c. Dokumentasi, yaitu metode pengumpulan data yang dilakukan dengan cara mengumpulkan datadata sekunder berupa literatur yang relevan dengan penelitian yang dilakukan. 


\section{HASIL DAN PEMBAHASAN}

Berdasarkan identifikasi variabel-variabel internal dan eksternal Toko Krisna Karya diatas, maka dapat dibuatkan tabel analisis internal faktor atau IFAS (Internal Factor Analysis Summary) dan tabel analisis strategi faktor eksternal atau EFAS (Eksternal Factor Analysis Summary). Nilai bobot didapatkan dari jawaban responden, kemudian nilai rating didapat dari nilai median dan selanjutnya nilai bobot dan nilai rating dikalikan sehingga mendapat nilai skor seperti dalam tabel berikut:

Tabel 2

Internal Faktor Analysis Summary (IFAS)

\begin{tabular}{|c|c|c|c|}
\hline Internal Faktor Analisis & Bobot & Rating & Nilai skor \\
\hline (1) & (2) & (3) & (4) \\
\hline \multicolumn{4}{|l|}{ KEKUATAN } \\
\hline 1. Tempat yang strategis & 0,12 & 3 & 0,36 \\
\hline 2. Harga yang lebih murah dari toko lain & 0,09 & 2 & 0,17 \\
\hline $\begin{array}{l}\text { 3. Mempunyai tempat produksi yang memenuhi } \\
\text { keinginan konsumen }\end{array}$ & 0,14 & 4 & 0,57 \\
\hline 4. Merupakan supplier bagi toko lain & 0,11 & 3 & 0,34 \\
\hline 5. Menyediakan pembelian online & 0,12 & 3 & 0,36 \\
\hline 6. Menjual berbagai macam bentuk dan ukuran produk & 0,14 & 4 & 0,57 \\
\hline \multicolumn{4}{|l|}{ KELEMAHAN } \\
\hline 1. Kurang mengadakan riset pasar & 0,09 & 2,5 & 0,24 \\
\hline 2. Promosi tidak berkesinambungan & 0,09 & 2,5 & 0,24 \\
\hline 3. Tempat parkir kurang memadai & 0,09 & 2,5 & 0,24 \\
\hline TOTAL & $\mathbf{1 , 0 0}$ & & 3,01 \\
\hline
\end{tabular}

Sumber: Data Diola, 2017 
Tabel 3

Eksternal Faktor Analysis Summary (EFAS)

\begin{tabular}{|c|c|c|c|}
\hline $\begin{array}{c}\text { Eksternal } \\
\text { Faktor Analisis }\end{array}$ & Bobot & Rating & Nilai skor \\
\hline$(1)$ & (2) & (3) & (4) \\
\hline \multicolumn{4}{|l|}{ PELUANG } \\
\hline $\begin{array}{l}\text { 1. Kecenderungan masyarakat dalam memilih hiasan } \\
\text { rumah. }\end{array}$ & 0,11 & 4,00 & 0,45 \\
\hline 2. Jaringan pemasok yang handal dan terpercaya & 0,11 & 3,50 & 0,38 \\
\hline $\begin{array}{l}\text { 3. Membangun hubungan yang baik dengan pelanggan } \\
\text { loyal }\end{array}$ & 0,11 & 4,00 & 0,45 \\
\hline 4. Kepercayaan masyarakat pada Toko Krisna Karya & 0,11 & 4,00 & 0,45 \\
\hline 5. Menjadi perhatian sampai di wisatawan & 0,12 & 4,00 & 0,46 \\
\hline 6. Berada di lingkungan kantor pemerintahan & 0,10 & 3,00 & 0,30 \\
\hline $\begin{array}{l}\text { 7. Berada pada salah satu tempat pusat kegiatan } \\
\text { masyarakat }\end{array}$ & 0,09 & 3,00 & 0,28 \\
\hline \multicolumn{4}{|l|}{ ANCAMAN } \\
\hline 1. Bahan baku produksi yang mahal & 0,06 & 2,00 & 0,12 \\
\hline 2. Bahan baku yang termasuk langka & 0,06 & 2,00 & 0,15 \\
\hline 3. Selera konsumen yang berubah-ubah & 0,08 & 3,00 & 0,24 \\
\hline $\begin{array}{l}\text { 4. Terdapat beberapa pesaing yang memproduksi jenis } \\
\text { souvenir lain }\end{array}$ & 0,03 & 1,00 & 0,03 \\
\hline TOTAL & $\mathbf{1 , 0 0}$ & & 3,31 \\
\hline
\end{tabular}

Sumber: Data Diola, 2017

Setelah diketahui jumlah nilai bobot dan jumlah nilai skor dari masing-masing faktor yang dianalisis maka langka yang selanjutnya adalah membuat matriks grand strategic dari peluang dan ancaman serta kekuatan dan kelemahan sebagaimana yang tampak pada diagram matriks berikut ini. 
PELUANG

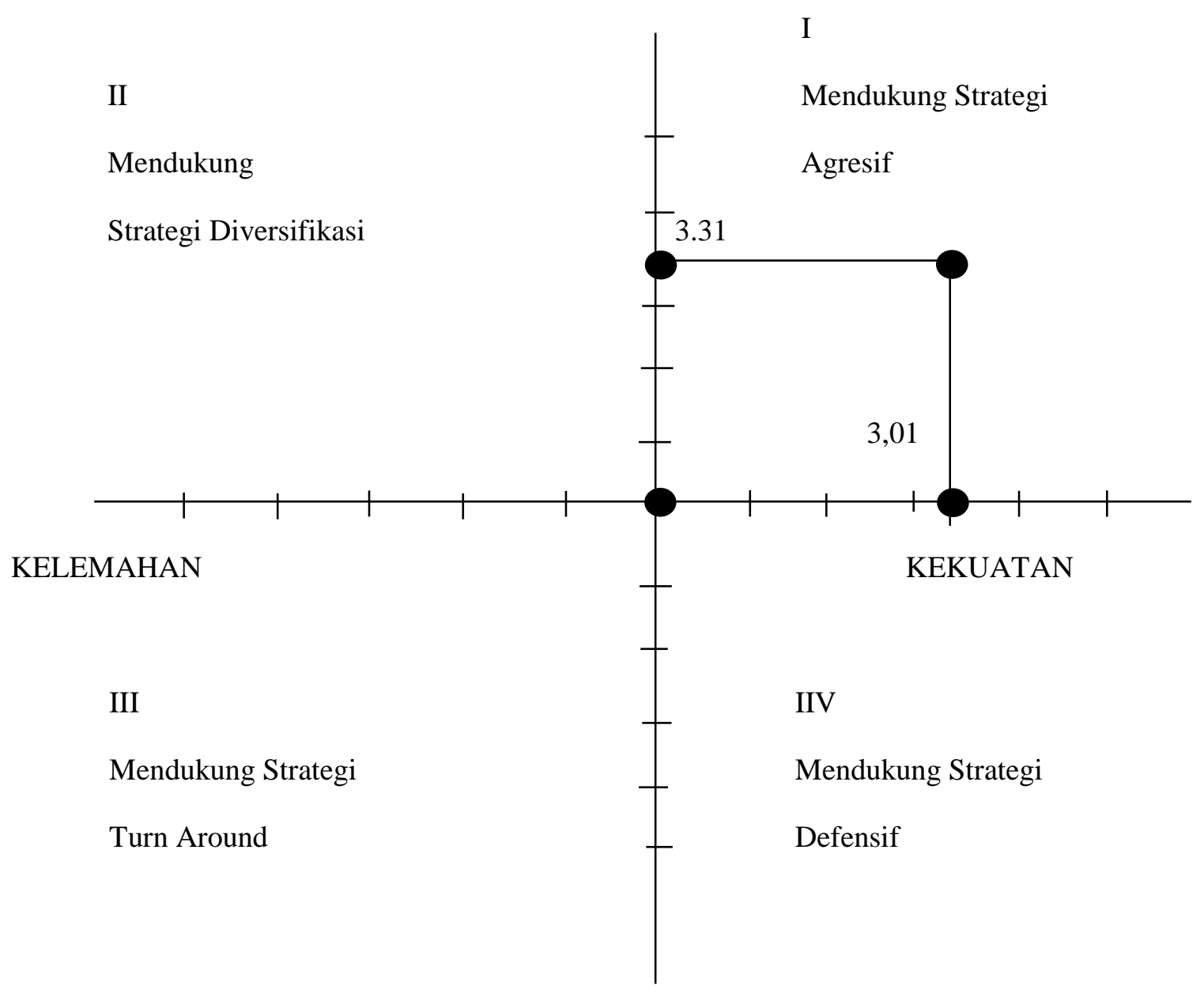

ANCAMAN

Gambar 2 Diagram Matriks (Grand Strategic)

Sumber: Data Diola, 2017 


\section{Kuadran I}

Kuadran ini memberikan gambaran bahwa product atau service dari organisasi bisnis yang mempunyai tingkat pertumbuhan demand dan potensial keuntungan atau profit yang tinggi sehingga membentuk market share yang tinggi. Maka, produk organisasi yang berada pada kuadran ini secara umum mempunyai tingkat revenue yang signifikan, sehingga strategi investasi mengarah pada kebutuhan untuk mempertahankan posisi yang sudah ada. Posisi ini sesuai dengan posisi kuadran I merupakan situasi posisi yang sangat menguntungkan. Usaha tersebut memiliki peluang dan kekuatan sehingga mampu memaksimalkan peluang yang ada. Strategi yang diterapkan cukup kuat, strategi dengan lokasi yang menguntungkan dalam mendukung kebijakan pertumbuhan yang agresif (Growth Oriented Strategy). Strategi agresif yang terdapat pada Toko Krisna Karya sebagai kekuatan yang paling diandalkan yaitu harga produk-produk jualan yang cukup murah dan terjangkau. Produksi souvenir yang terdapat pada Toko Krisna Karya mempunyai kualitas tinggi. Sehingga hal tersebut menjadi sebuah modal kepercayaan masyarakat sebagi konsumen yang cerdas seperti saat sekarang.

\section{Kuadran II}

Kuadran ini menggambarkan posisi produk organisasi bisnis berada pada tingkat kebutuhan pasar atau market growth yang tinggi tetapi market share yang terbentuk rendah, sehingga membutuhkan investasi yang signifikan atau berlebih dengan harapan dapat memperoleh market share yang tinggi dan dapat menuju pada posisi kuadran Star. Penanganan yang salah dapat mengakibatkan posisi beralih pada posisi kuadran Dog. Kuadran ini sesuai dengan posisi kuadran II meskipun menghadapi berbagai macam ancaman usaha tersebut masih memiliki kekuatan dari segi internal. Strategi yang harus diterapkan adalah menggunakan kekuatan untuk memanfaatkan peluang jangka panjang dengan cara strategi operasional (produk pasar). Pemilik Toko Krisna Karya telah memikirkan dan mengantisipasi strategi yang ada dalam bisnisnya. Keinginan konsumen dalam memilih berbagai macam bentuk dan ukuran merupakan pengantisipasian yang diambil oleh Toko Krisna Karya karena masyarakat sebagai konsumen lebih cenderung memiilih hiasan rumah. Terpenuhinya keinginan konsumen maka terjalinlah hubungan yang baik dan mendapatkan konsumen yang loyal terhadap Toko Krisna Karya walaupun bisa dilihat pada saat zaman serba modern dan canggih dengan bisnis online yang ada yang menjadi pesaing dan tantangan pada Toko Krisna Karya.

\section{Kuadran III}

Kuadran ini menggambarkan posisi produk dan organisasi secara umum berada posisi yang tidak menguntungkan secara finansial, karena market share dan market demand secara keseluruhan turun. Sama halnya dengan posisi kuadran III Usaha menghadapi peluang pasar yang sangat besar tetapi di lain pihak, ia menghadapi beberapa kendala/kelemahan internal. Fokus strategi usaha ini adalah meminimalkan masalah-masalah internal usaha sehingga dapat merebut pasar yang lebih baik. Untuk merebut pasar yang ada pada saat ini dengan kondisi kuadran dog/kuadran III penuh dengan tantangan. Salah satu cara yang dilakukan Toko Krisna Karya dalam meminimalisir masalah-masalah tetap memberdayakan sumber daya manusia untuk berinovasi dengan produk-produk yang dipasarkan. Lebih menonjolkan produk yang mampu merebut hati konsumen dan tuntutan pasar. Sehingga kendala yang dapat teratasi sedikit demi sedikit. Sangat kurang melakukan riset pasar sehingga sangat kurang mengetahui apa sebenarnya keinginan pasar pada umumnya dan khususnya konsumen yang memang menjadi pecinta souvenir kayu Ebony. Lahan parkir yang menjadi fokus dan terpenting karena hal tesebut menjadi kelemahan yang paling mendasar. Serta promosi produk yang tidak berkesinambungan, oleh karenanya peluang bagi pesaing lainnya mampu menarik hati konsumen baru lainnya. Akan tetapi tantangan itu mampu merebut pasar dengan konsistensi produk-produk yang sangat berkualitas. 


\section{Kuadran IV}

Kuadran ini menggambarkan posisi produk dan organisasi secara umum berada posisi pertumbuhan market demand yang lambat karena tidak disertai dengan pertumbuhan pelanggan, sehingga revenue yang didapat oleh produk dari kuadran Star dibutuhkan untuk re-investasi. Sehingga membutuhkan strategi pemasaran yang lebih efisien dan efektif agar produk dapat lebih dikenal dan dapat meningkatkan aspek market share-nya dan posisi kuadran IV merupakan situasi yang sangat tidak menguntungkan, usaha tersebut menghadapi berbagai ancaman dan kelemahan internal. Bahan baku yang langka sehingga membuat harganya juga pun menjadi sangat mahal karena dalam pemenuhan produk awalnya sangat sulit. Kondisi ini pun mengurangi langka bagi pihak Toko Krisna Karya untuk mengadakan riset pasar dan promosi yang sangat kurang. Hal ini yang menjadi kelemahan yang sangat penting untuk diperhatikan agar tetap bertahan dalam penjualan produk-produk souvenir nya.

Berdasarkan internal-eksternal matriks dengan nilai total skor IFAS $=3,01$ dan EFAS $=3,31$ diatas kita dapat melihat beberapa kekuatan, kelemahan peluang dan ancaman uang dimiliki usaha souvenir Toko Krisna Karya. Untuk itudengan memahami dimana kekuatan atau kelemahan usaha dalam persaingan, maka langka selanjutnya yaitu menyusun strategi yang sesuai untuk menghadapi persaingan di masa depan dengan demikian, matriks SWOT yang berisi gambaran tentang berbagai peluang dan ancaman lingkungan luar yang dihadapi oleh usaha diperhadapkan pada pada kekuatan dan kelemahan yang dimilikinya dengan berbagai alternatif strategi dapat dirumuskan berdasarkan SWOT. Keunggulan dengan menggunakan matriks SWOT ini adalah kita dapat dengan mudah memformulasikan strategi yang kita peroleh berdasarkan gabungan internal dan eksternal faktor. Untuk mengetahui lebih jelas aplikasi dari empat alternatif strategi yang disatukan dalam SWOT dapat dilihat dalam tabel diagram matriks SWOT penentuan strategi perusahaan sebagai berikut: 
Tabel 4

Diagram Matriks SWOT

Penentuan Strategi Toko Krisna Karya

\begin{tabular}{|c|c|c|}
\hline EFAS & $\begin{array}{l}\text { STRENGHT(S) } \\
\text { - } \quad \text { Tempat yang strategis } \\
\text { - Harga yang lebih murah dari } \\
\text { toko lain } \\
\text { - Mempunyai tempat produksi } \\
\text { yang memenuhi keinginan } \\
\text { konsumen } \\
\text { - Merupakan supplier bagi toko } \\
\text { lain } \\
\text { - Menyediakan pembelian online } \\
\text { - Menjual berbagai macam } \\
\text { bentuk dan ukuran produk }\end{array}$ & $\begin{array}{l}\text { WEAKNESSES }(\mathrm{W}) \\
\text { - } \quad \text { Kurang mengadakan riset } \\
\text { pasar } \\
\text { - } \text { Promosi tidak } \\
\text { berkesinambungan } \\
\text { - } \text { Tempat parkir kurang } \\
\text { memadai }\end{array}$ \\
\hline $\begin{array}{l}\text { OPPORTUNITIES (O) } \\
\text { - Kecenderungan } \\
\text { masyarakat dalam } \\
\text { memilih hiasan rumah. } \\
\text { - Jaringan pemasok yang } \\
\text { handal dan terpercaya } \\
\text { - } \text { Membangun hubungan } \\
\text { yang baik dengan } \\
\text { pelanggan loyal } \\
\text { Menjadi perhatian } \\
\text { sampai di wisatawan } \\
\text { Berada dilingkungan } \\
\text { kantor pemerintahan } \\
\text { Berada pada salah satu } \\
\text { tempat pusat kegiatan } \\
\text { masyarakat }\end{array}$ & $\begin{array}{l}\text { STRATEGI SO } \\
\text { - Menjual stok barang dengan } \\
\text { harga yang sangat murah } \\
\text { dengan jaringan pemasok } \\
\text { handal untuk merebut } \\
\text { pelanggan loyal. } \\
\text { - Menggunakan medsos sebagai } \\
\text { cara untuk memudahkan } \\
\text { wisatawan dalam membeli } \\
\text { produk Krisna Karya. }\end{array}$ & $\begin{array}{l}\text { STRATEGI WO } \\
\text { - } \quad \text { Perluasan area parkir } \\
\text { dalam mengantisipasi } \\
\text { kelonjakan kunjungan } \\
\text { konsumen di hari-hri } \\
\text { tertentu. } \\
\text { - Peluang dalam promosi } \\
\text { untuk menarik minat calon } \\
\text { konsumen. }\end{array}$ \\
\hline $\begin{array}{l}\text { THREATS }(\mathrm{T}) \\
\text { - } \quad \text { Bahan baku produksi } \\
\text { yang mahal } \\
\text { - } \quad \text { Bahan baku yang } \\
\text { termasuk langka } \\
\text { - } \quad \text { Selera konsumen yang } \\
\text { berubah-ubah } \\
\text { - Terdapat beberapa } \\
\text { pesaing yang } \\
\text { memproduksi jenis } \\
\text { souvenir lain }\end{array}$ & $\begin{array}{l}\text { STRATEGI ST } \\
\text { - Memperlancar pemasokan } \\
\text { barang secara maksimal. } \\
\text { - Pemenuhan bahan untuk } \\
\text { menciptakan produk baru yang } \\
\text { inovatif. }\end{array}$ & $\begin{array}{l}\text { STRATEGI WT } \\
\text { - Melakukan promosi } \\
\text { dengan produk yang } \\
\text { terbaru. } \\
\text { - } \\
\text { Riset pasar lebih aktifkan } \\
\text { agar diketahui selera } \\
\text { konsumen. }\end{array}$ \\
\hline
\end{tabular}

Sumber: Data Diola, 2017 
Jaura

Berdasarkan hasil analisis tabel matriks SWOT diatas diperoleh beberapa alternatif strategi yaitu SO, strategi WO, strategi ST dan strategi WT.Alternatif strategi yang diperoleh adalah:

1) Strategi S-O:

(a) Menjual stok barang dengan harga yang sangat murah dengan jaringan pemasok handal untuk merebut pelanggan loyal karena konsumen saat ini mencari yang murah dan mudah didapat hal tersebut mampu menarik minat bagi calon konsumen Toko Krisna Karya,

(b) Pemilik toko souvenir menggunakan medsos sebagai cara untuk memudahkan wisatawan dalam membeli produk Krisna Karya dengan beberapa akses menjadikan hal tersebut sebagai nilai jual dan promosi tentang produk-produk souvenir Toko Krisna Karya.

2) Strategi W-O:

(a) Perluasan area parkir dalam mengantisipasi kelonjakan kunjungan konsumen di hari-hari tertentu.

(b) Peluang dalam promosi untuk menarik minat calon konsumen.

3) Strategi S-T:

(a) Memperlancar pemasokan barang secara maksimal.

(b) Pemenuhan bahan untuk menciptakan produk baru yang inovatif.

4) Strategi W-T:

(a) Melakukan promosi dengan produk yang terbaru

(b) Riset pasar lebih diaktifkan agar di ketahui selera konsumen.

Berdasarkan hasil data diatas, selanjutnya penentuan strategi perusahaan dengan melihat kondisi internal maupun kondisi eksternal perusahaan dimana faktor peluang dan kekuatan sangat berperan aktif dalam peningkatan volume penjualan produk-produk Toko Krisna Karya hal tersebut dapat dibuktikan dengan kondisi perusahaan memperoleh nilai rating 4. Sehingga dapat disimpulkan dari hasil penelitian pada usaha Toko Krisna Karya sebaiknya menggunakan strategi SO yakni dengan memanfaatkan peluang serta kekuatan dari semua lini perusahaan secara optimal agar mampu meraih pangsa pasar, dan meningkatkan kualitas produk dengan berbagai variasi bentuk produk dengan satu tujuan yakni penjualan yang tinggi.

\section{KESIMPULAN DAN SARAN KESIMPULAN}

Berdasarkan hasil pembahasan yang dikemukakan berdasarkan pada hasil penelitian sebelumnya dapat ditarik kesimpulan bahwa pada hasil analisis SWOT, menunjukkan internal strategic factor analysis summary (IFAS)/ kekuatan dan kelemahan sebesar 3,01 dan external strategic factor analysis summary (EFAS)/peluang dan ancaman usaha Toko Krisna Karya dengan total 3,31 dari hasil tersebut sebaiknya usaha souvenir Toko Krisna Karya menggunakan strategi SO yaitu dengan memanfaatkan semua kekuatan usaha dalam rangka merebut dan memanfaatkan peluang yang ada secara optimal.

\section{SARAN}

1) Toko Krisna Karya sebaiknya lebih memperhatikan kelemahan-kelemahan yang ada seperti:

(1) melakukan riset pasar karena dengan melakukan riset pasar pihak toko dapat mengetahui apa yang menjadi keinginan pasar pada umumnya dan khususnya konsumen pecinta souvenir kayu Ebony. Lebih melihat dan memperhatikan peluang yang ada apa lagi saat zaman sekarang yang canggih dengan ilmu teknologi yang dikenal sebagai kaum millennial yang inginkan sesuatu secara mudah,cepat dan murah. Memesan sesuatu melalui gadget ataupun android tanpa lagi ke tempatnya 
(toko). Hal ini tentunya menjadi tantangan terbesar sehingga Toko Krisna harus mencarikan solusi terbaik dan tetap update agar mampu bertahan dalam pangsa pasar saat ini.

(2) Promosi produk yang tidak berkesinambungan, oleh karenanya peluang bagi pesaing lainnya mampu menarik hati konsumen baru lainnya. Sebaiknya pihak toko lebih memperhatikan kelemahan-kelemahan yang ada agar mampu bertahan dengan produk-produknya

(3) Serta perluasan lahan parkir yang menjadi fokus dan terpenting bagi Toko Krisna Karya karena hal tersebut menjadi kelemahan yang paling mendasar agar dapat mengantisipasi kelonjakan kunjungan konsumen di hari-hari tertentu.

2) Toko Krisna Karya juga harus memperhatikan ancaman-ancaman yang ada seperti:

(1) Bahan baku yang termasuk langka sehingga untuk memperolehnya butuh banyak cara dan dana, karena bahan baku pasti akan sangat mahal.

(2) Selera konsumen yang pastinya akan berubah-ubah karena melihat trend saat ini sehingga pemilik toko harus punya cara lain untuk dapat mencari solusi terbaik.

(3) Dan juga tak kala pentingnya yang harus diperhatikan ancaman dari pesaing-pesaing yang ada saat ini karena proses market yang dilakukan tidak hanya toko yang stay yang menjual tapi mereka memasarkan dengan cara online shop.

3) Bagi peneliti diharapkan kepada peneliti lain yang hendak mengadakan penelitian sejenis, hendaknya menjadikan hasil penelitian ini sebagai bahan referensi agar diperoleh hasil yang lebih optimal.

\section{REFERENSI}

Alma, Buchari. (2014). Manajemen Pemasaran dan Pemasaran Jasa. Bandung: CV. Alfabeta.

afrillita. (2013). analisis SWOT Dalam Menentukan Strategi Pemasaran Sepeda Motor Pada PT Samekarindo Indah Di Samarinda. Ejurnal Administrasi Bisnis 2013, 1(1):56-70

Amelia. (2014). Rentabilitas Usaha Kerajinan Kayu Hitam Pada Industri Krisna Karya di Kecamatan Palu Timur Kota Palu Sulawesi Tengah. Jurnal untad.ac.id/jurnal/index.php/Agrotekbis/article/download/3534/2553. Diakses pada Tanggal 03 Januari 2017.

Kotler, Philip \& Amstrong, Gary. (2012). Prinsip Prinsip Pemasaran. Edisi 13, jilid 1. Jakarta: Erlangga.

Kotler, Philip, \& Keller, Kevin Lane. (2009). Manajemen Pemasaran Jilid 1 Edisi 12. Indonesia: PT. Macana Jaya Cemerlang.

Kotler, Philip, \& Keller, Kevin Lane. (2009). Manajemen Pemasaran Jilid 1 Edisi 13. Jakarta: Erlangga.

Malau Harman. (2017). Manajemen Pemasaran. Bandung: CV. Alfabeta.

Rangkuti Freddy. (2015). Teknik Membedah Kasus Bisnis Analisis SWOT. Jakarta: PT. Gramedia Pustaka Utama.

Ratzs. (2011). https://rats3x.wordpress.com Portofolio-Aplikasi-Hasil-dari-PerencanaanStrategis-Sistem-Informasi. . Diakses 19 Februari 2018 .

Sabariah, E. (2016). Manajemen Strategis. Yogyakarta: Pustaka Pelajar.

Sugiyono. (2014). Memahami Penelitian Kualitatif. Bandung: CV. Alfabeta. 
Jaura

Sugiyono. (2014). Metode Penelitian Bisnis. Bandung: CV. Alfabeta.

Tzu, Sun. (2004). Strategi Untuk Pemasaran. Batam: Karisma Publishing Group.

Umar Husein. (2000). Metode Penelitian Aplikasi dalam Pemasaran. Jakarta: Gramedia Pustaka Utama. 